\title{
Popularity of the Consumption of Dietary Supplements and its Associated Factors among Students in an Egyptian University: A Cross-sectional Study
}

\author{
Nelly Hegazy ${ }^{1 *}$, Hanan Ali Sayed ${ }^{1}$, Ahmed Ali Hasan $^{2}$, Marwa Rashad Salem $^{3}$ \\ ${ }^{1}$ Department of Community, Environmental and Occupational Medicine, Faculty of Medicine, Helwan University, Helwan, Egypt; \\ ${ }^{2}$ Department of Health and Nutrition, Faculty of Physical Education for Boys, Helwan University, Helwan, Egypt; ${ }^{3}$ Department \\ of Public Health and Community Medicine, Faculty of Medicine, Cairo University, Cairo, Egypt
}

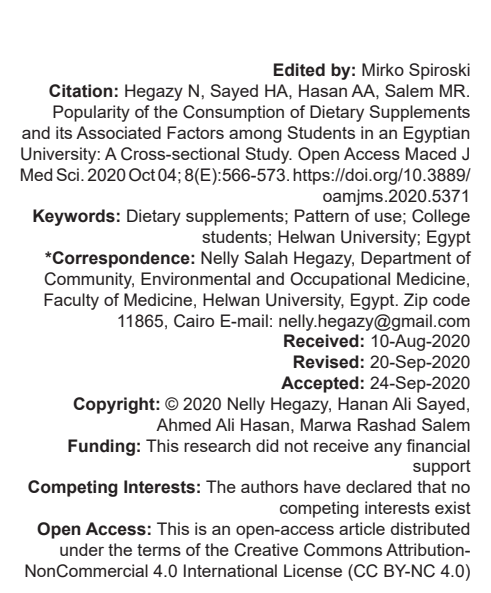

\section{Abstract}

BACKGROUND: Dietary supplements (DS) use has substantially become prevalent worldwide. However, a limited number of studies have addressed the consumption of DS among college students.

AIM: The objective of the study was to explore the prevalence of DS use among college students in an Egyptian college, their motives for DS use, and the association with sociodemographic and lifestyle factors.

METHODS: A cross-sectional study was conducted on 180 (18-25 years) college students at Helwan University. A self-administered questionnaire that included sociodemographic and lifestyle characteristics, DS use, commonly used types, reasons for use, and sources of information was employed.

RESULTS: More than two-thirds of the participants (117 students) have used DS with no difference among sex except for the types and motives for use $(p<0.001)$. The most used types were amino acids and proteins, multivitamins and minerals, and weight-loss herbals. Male students mainly used amino acids and proteins (54.7\%), multivitamins and minerals (17.2\%), for building muscles (50\%), gaining more energy (14\%), and maintaining good health (14\%). Female students consumed multivitamins and minerals $(35.8 \%)$, weight-loss herbals $(28.3 \%)$, for health promotion $(34 \%)$ and weight management $(28.3 \%)$. The main sources of information were the internet, health-care providers, and coaches. Male users depended primarily on the internet; however, female users received information from health-care providers $(p<0.001)$. Practicing exercise, non-smoking, and dietary patterns were associated with DS use.

CONCLUSION: DS use is remarkably common among college students in Egypt since their freshmen year. The findings highlight an urgent need to raise students' awareness regarding the appropriate use of DS from reliable sources to control DS use and prevent adverse effects.

\section{Introduction}

The use of dietary supplements (DS), manufactured products intended to enrich the diet with vitamins, minerals, herbs, and amino acids, has substantially increased, mainly in the United States of America (USA), Europe, and the Middle East [1], [2]

Unlike drugs, DS is not evaluated for safety and efficacy before obtaining permission for sale; therefore, it may carry the risk of being contaminated or adulterated [3]. In addition, DS has become businessworthy rather than a supplement of health and nutritional value. Hence, it is now available as over the counter products in supermarkets and pharmacies. In addition, they are purchased on the internet without any formal supervision; they are also heavily advertised on television [4], [5].

The global DS market has dramatically expanded and is expected to reach USD 278.02 billion by 2024 . Still, the DS market is an emerging one in the Middle East and Africa region; South Africa continues to be the biggest market in the region, though. While Egypt has witnessed a similar surge in the DS sales in 2017 , especially for vitamins and minerals, because of the public lack of awareness about healthy food, and the strong desire to compensate for poor-eating habits and boost the immune system [6], [7], [8].

The National Institute of Health reported that DS use is more common among those who are physically active, non-smoker, highly aware of healthy lifestyles and diets, and have lower body mass index (BMI) [9]. College students are a special group that shares a variety of characteristics and similar lifestyles, though. Hence, this group may have distinct patterns of DS use [10]. To this end, many studies were interested in assessing the prevalence of DS use among college students in different countries. Some studies that were conducted among college students in one of the universities of the United Arab Emirates (UAE) and Italy have shown that around $40 \%$ of participants have 
regularly used DS, while in Qatar and Australia, more than two-thirds of the participants have used DS [11], [12], [13], [14]. The participants reported that coaches, friends, the internet, family members, and health-care providers were the main sources of information about DS [15], [16], [17].

Despite the popularity of DS use in Egypt, there is paucity in the documentation of the DS use, especially among college students. This study aimed to explore the prevalence of DS use, determine reasons for their use, and assess the associated factors of DS use among students at the College of Law, Helwan University in Egypt.

\section{Methods}

\section{Study design and setting}

This was an exploratory cross-sectional study conducted at the main campus of Helwan University in Ain Helwan, which is $30 \mathrm{~km}$ south of Cairo governorate.

\section{Sample size and sampling technique}

The target population was students from the College of Law, as a sample of the colleges which are characterized by the theoretical nature of their teaching and lack of specialization for undergraduates. Therefore, students are easily accessible, as they have more free time than those in any other practical college. Besides, the Faculty of Law gave the researchers the approval and facilitated conducting the study with its students.

A consecutive sample of 252 students from the College of Law was recruited from February 2019 to April 2019. The researchers excluded 72 questionnaires; 47 questionnaires were for incomplete responses, and 25 questionnaires were for chronic medical conditions. The final sample became 180 students.

\section{Ethics approval and consent to participate}

The Ethical Review Committee in the Faculty of Medicine, Cairo University revised and approved the study protocol. The protocol was examined and registered in July 2017 with report number N-63-2017. Informed written consent was obtained from subjects who agreed to participate in the study after proper orientation about the purpose of the study and assured confidentiality.

\section{Inclusion criteria}

Egyptian undergraduates (males and females) from freshmen to senior years.

\section{Exclusion criteria}

Students who had any medical conditions that lasted more than 6 months (heart diseaseshypertension-diabetes mellitus-kidney diseasesthyroid dysfunction-cancer-autoimmune diseases).

\section{Data collection tool}

The researchers used a structured, selfadministered questionnaire [11], [13], [14], [15]. The original form was translated by two language experts into Arabic and back-translated to English by another two independent language experts.

The questionnaire was pretested among 10 college students (beyond the sample size), as a smallscale pilot study, before executing the field survey to ensure the clarity and comprehension of the questions. Some questions were modified based on the pilot study results; besides, three expert professors checked its content validity; then, the questionnaire was circulated among the authors, in its final version, to approve it as the data collection tool. The final questionnaire was expected to take $15 \mathrm{~min}$ to be completed and was administered in Arabic only.

Data were collected by one trained researcher to enhance the reliability of the study and minimize the interobserver variation in data collection. The researcher distributed the questionnaire to the students at the respective college in front of their classrooms, while they were waiting for a lecture or have just finished the class; the students completed the questionnaire voluntarily. Before administering it, the researcher gave a short introduction about the objectives of the study and the questionnaire and defined DS as products intended to supplement the diet, including vitamins, minerals, herbs, and amino acids.

\section{The questionnaire included three parts}

\section{Part one}

Sociodemographic data, including age, sex, and academic year, marital status, and place of accommodation

Anthropometric data, including weight and height (self-reported) to calculate the BMI (calculated as weight in kilograms divided by height in meter squared, or $\mathrm{kg} / \mathrm{m}^{2}$ )

Chronic medical conditions that lasted more than 6 months (heart diseases- hypertension- diabetes mellitus-kidney diseases- thyroid dysfunction-cancerautoimmune diseases).

\section{Part two: lifestyle characteristics}

Nutrition behavior; types of diet followed (high protein - low fat - no specific diet followed) and their satisfaction with food alone to fulfill their nutritional needs 
Practice regular exercise, reasons, and duration in minutes per week

Smoking status (current cigarette smoker ex-smoker - never smoke)

Self-rated health

status

(excellent-good-fair-below).

\section{Part three: DS use}

Ever use DSs throughout their life, and if $\mathrm{NO}$, causes of not using DS

The purpose of DS use (i.e., maintaining or improving health, beauty benefits, weight loss, building muscle, giving more energy, and enhancing the diet)

Sources of information about DS (internet, coaches, friends, family members, newspaper and magazine, and health-care providers)

Commonly used types by the participants (vitamins and minerals- non-vitamins and non-minerals "amino acids/protein- herbals for weight loss- creatinineOmega 3") Duration of DS s use.

\section{Data analysis}

Data were gathered, checked, and timely reviewed to ensure the quality and completeness of questionnaire forms. Pre-coded data were fed into the computer using the Statistical Package of the Social Science Software program (SPSS for Windows, version 20.1, SPSS Inc., Chicago, IL, USA) for statistical analysis. Categorical variables were expressed in frequency and percentages. Continuous variables were expressed as range, mean \pm standard deviation. Chisquare test or Fisher's exact test applied to assess significant differences for categorical characteristics of the demographic and lifestyle characteristics for males and females, and DS users and non-users. Logistic regression analyses were applied to examine the relationships between selected demographic and lifestyle characteristics and DS use, where odds ratios and their $95 \%$ confidence intervals were computed. $p<0.05$ was considered statistically significant. Tables and figures were used to illustrate the information.

\section{Results}

\section{Sample characteristics}

The study included 180 students, equally divided between males and females. The sample comprised students from the four academic years of college; the mean age of the participants was $20.9 \pm$ 1.43 years, and the range was from 18 to 25 years old.
The majority of students were single, non-smokers, and living with their families. More than one-third of the students were overweight (BMI $\geq 25)$. Table 1 shows these characteristics of the sample.

Two-thirds of the male students were practicing regular exercises, primarily to increase their muscle masses, and mostly for more than 300 min/week. Whereas $46.7 \%$ of female students were practicing regular exercises, commonly for 30-150 min/week; their prime motive was to lose weight, which is significantly different from male students $(p<0.001)$.

\section{Lifestyle characteristics associated with DS use}

As showed in Table 2, DS has been used by 117 (65\%) of students: $54.7 \%$ males and $45.3 \%$ females with no significant difference $(p=0.08)$. DS use was the minimum in the first academic year and increased to reach the maximum in the last year $(p<0.001)$. Regarding nutrition behavior, nearly half of the users preferred to follow a high protein diet, and one-third went for a low-fat diet $(p<0.001)$. However, three-quarters of the users believed that food alone is not enough to satisfy their nutritional needs ( $p<0.001)$. Besides, more than two-thirds of DS users rated their health (excellent/good) versus the non-users who rated their health as (fair/below) $(p<0.001)$.

Nearly all the DS users were non-smokers and were also engaging in doing regular exercise more than the non-users $(66.7 \%$ vs. $31.7 \%)$ and for a longer duration (more than 300 min vs. 30-150 min, respectively) ( $p<0.001)$. The main motives for DS users to do exercise were to increase the muscle mass $(34.6 \%)$, lose weight $(26.9 \%)$, or just to relieve stress and improve their fitness $(p<0.006)$.

\section{Patterns of DS use among male and female}

users

Amino acids/proteins were the most common DS used by half of the males, followed by multivitamins and minerals $17 \%$ then creatinine $9.4 \%$ while females commonly took multivitamins and minerals $35.8 \%$, followed by herbals for weight loss $28.3 \%$, then individual minerals (iron, folic acid, zinc) $20.8 \%$ ( $p<0.001$ ), as shown in Table 3.

In terms of reasons for DS use, half of the male users primarily sought to build their muscles, then gain more energy and promote or maintain good health $(28 \%)$. Health benefit was the prime motive for female users $(34 \%)$, followed by body shape and weight management $(28.3 \%)$. As for sources of information about DS, male users relied mainly on the internet $(23.4 \%)$ then coaches $(20.3 \%)$. However, health-care providers (physicians or pharmacists) were the most popular source for females $(30.2 \%)$, then the internet $(24.5 \%)$, and family members $(22.6 \%)$. 
Table 1: Demographic and lifestyle characteristics of the enrolled students $(n=180)$

\begin{tabular}{|c|c|c|c|c|}
\hline Variables & Total, $n(\%)(n=180)$ & Males, n (\%) $90(50)$ & Females, n (\%) $90(50)$ & $p$-value ${ }^{b}$ \\
\hline \multicolumn{5}{|l|}{ Academic years } \\
\hline $1^{\text {st }}$ year & $44(24.4)$ & $21(23.3)$ & $23(25.6)$ & \multirow[t]{4}{*}{0.6} \\
\hline $2^{\text {nd }}$ year & $42(23.3)$ & $20(22.2)$ & $22(24.4)$ & \\
\hline $3^{\text {rd }}$ year & $46(25.6)$ & $21(23.3)$ & $25(27.8)$ & \\
\hline $4^{\text {th }}$ year & $48(26.7)$ & $28(31.2)$ & $20(22.2)$ & \\
\hline \multicolumn{5}{|l|}{ Marital status } \\
\hline Single & 169 (93.9) & $88(97.8)$ & $81(90)$ & \multirow[t]{2}{*}{$0.029^{*}$} \\
\hline Married & $11(6.1)$ & $2(2.2)$ & $9(10)$ & \\
\hline \multicolumn{5}{|l|}{ Living } \\
\hline With family & $144(80)$ & $61(67.8)$ & $83(92.2)$ & \multirow[t]{3}{*}{$0.001^{*}$} \\
\hline With friends & $20(11.1)$ & $20(22.2)$ & $0(0)$ & \\
\hline In university Campus & $16(8.9$ & $9(10)$ & $7(7.8)$ & \\
\hline \multicolumn{5}{|l|}{$B M l^{\mathrm{a}}$} \\
\hline Average BMI (18.5-24.9) & $99(55)$ & $54(60)$ & $45(50)$ & \multirow[t]{3}{*}{0.174} \\
\hline Overweight BMI (25-29.9) & $57(31.7)$ & $28(31.1)$ & $29(32.2)$ & \\
\hline Obese $\mathrm{BMI} \geq 30$ & $24(13.3)$ & $8(8.9)$ & $16(17.8)$ & \\
\hline \multicolumn{5}{|l|}{ Type of diet followed } \\
\hline High protein diet & $59(32.8)$ & $34(37.8)$ & $25(27.8)$ & \multirow[t]{3}{*}{$0.03^{*}$} \\
\hline Low fat diet & $47(26.1)$ & $16(17.8)$ & $31(34.4)$ & \\
\hline No specific diet followed & $74(41.1)$ & $40(44.4)$ & $34(37.8)$ & \\
\hline \multicolumn{5}{|c|}{ Food alone is enough to satisfy your nutritional needs } \\
\hline Yes & $68(37.8)$ & $31(34.4)$ & $37(41.1)$ & \multirow[t]{2}{*}{0.35} \\
\hline No & $112(62.2)$ & $59(65.6)$ & $53(58.9)$ & \\
\hline \multicolumn{5}{|l|}{ Self-rated health status } \\
\hline Excellent & $32(17.8)$ & $24(26.7)$ & $8(8.9)$ & \multirow[t]{4}{*}{$0.008^{*}$} \\
\hline Good & $66(36.7)$ & $27(30)$ & $39(43.3)$ & \\
\hline Fair & $67(37.2)$ & $34(37.8)$ & $33(36.7)$ & \\
\hline Below & $15(8.3)$ & $5(5.6)$ & $10(11.1)$ & \\
\hline \multicolumn{5}{|l|}{ Smoking } \\
\hline Current cigarette smoker & $22(12.2)$ & $19(21.1)$ & $3(3.3)$ & \multirow[t]{3}{*}{$0.001^{*}$} \\
\hline Ex-smoker & $7(3.9)$ & $7(7.8)$ & $0(0)$ & \\
\hline Never smoke & $151(83.9)$ & $64(71.1)$ & $87(96.7)$ & \\
\hline \multicolumn{5}{|l|}{ Practice regular exercise ${ }^{c}$} \\
\hline Yes & $98(54.4)$ & $56(62.2)$ & $42(46.7)$ & \multirow[t]{2}{*}{$0.036^{*}$} \\
\hline No & $82(45.6)$ & $34(37.8)$ & $48(53.3)$ & \\
\hline \multicolumn{5}{|c|}{ Reasons from regular exercise $(n=98)$} \\
\hline Increase muscle mass & $30(30.6)$ & $30(53.6)$ & $0(0)$ & \multirow[t]{4}{*}{$0.001^{*}$} \\
\hline Fitness and relief stress & $29(29.6)$ & $10(17.9)$ & $19(45.2)$ & \\
\hline Weight loss & $25(25.5)$ & $4(7.1)$ & $21(50)$ & \\
\hline Win the competition & $14(14.3)$ & $12(21.4)$ & $2(4.8)$ & \\
\hline \multicolumn{5}{|c|}{ Exercise duration/week/min $(n=98)$} \\
\hline$<30 \min$ & $4(4.1)$ & $2(3.6)$ & $2(4.8)$ & \multirow[t]{4}{*}{$0.001^{*}$} \\
\hline $30-150 \mathrm{~min}$ & $26(26.5)$ & $5(8.9)$ & $21(50)$ & \\
\hline $150-300 \mathrm{~min}$ & $27(27.6)$ & $9(16.1)$ & $18(42.9)$ & \\
\hline More than $300 \mathrm{~min}$ & $41(41.8)$ & $40(71.4)$ & $1(2.4)$ & \\
\hline
\end{tabular}

Half of the male users obtained DS from the internet (websites and social media), followed by DS stores $(25 \%)$, while $56 \%$ of females purchased DS from pharmacies, followed by the internet (35\%). Furthermore, the majority of males used to consume DS for a longer duration ( $6 \mathrm{~ms}-1$ year) than females who commonly used DS from (1-4 weeks).

On the other hand, Figure 1 illustrates the main reasons that non-users provided for not consuming DS. Expenses were the main challenge that more

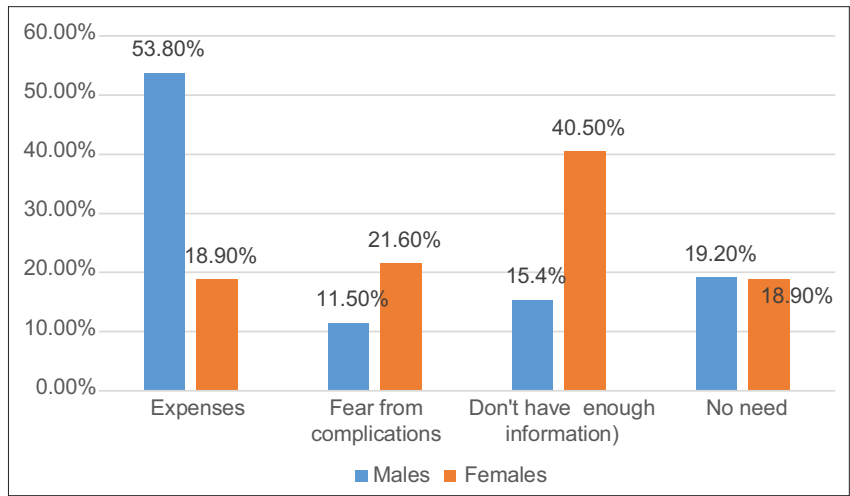

Figure 1: Causes of not using the dietary supplements among the non-users, males and female students $(n=63) .{ }^{*} p=0.02$ than one-half of male non-users encountered, while the lack of proper knowledge on DS was the primary reason for $40 \%$ of female non-users $(p=0.02)$.

\section{The relationships between selected} demographic and lifestyle characteristics and DS

The odds ratios and $95 \%$ confidence interval (Cl) of logistic regression analysis, as presented in Table 4, illustrate the relationships between several demographic and lifestyle characteristics and DS use. Not only did DS use increase significantly by age (e.g., the fourth-year students were 11 times more than the $1^{\text {st }}$-year students regarding DS use) but it also increased with $\mathrm{BMI} \geq 25$ and the participants who rated their health as excellent/good. Regarding the dietary patterns, DS use was 4 times higher among students who were not satisfied with food alone to fulfill their nutritional needs, and 10 times higher among those following a high protein diet. Furthermore, practicing regular exercise was significantly four times higher with DS use, either for muscle gaining, winning a competition (odds ratio $=7.1$ ) or weight loss (odds ratio $=3.7)$. 
Table 2: Demographic and lifestyle characteristics for DSs users and non-users $(n=180)$

\begin{tabular}{|c|c|c|c|}
\hline Variables & $\begin{array}{l}\text { DS users, } \\
\mathrm{n}(\%)\end{array}$ & $\begin{array}{l}\text { DS non- } \\
\text { user, n (\%) }\end{array}$ & $p$-value ${ }^{b}$ \\
\hline Total & $117(65)$ & $63(35)$ & - \\
\hline \multicolumn{4}{|l|}{ Sex } \\
\hline Male & $64(54.7)$ & $26(41.3)$ & \multirow[t]{2}{*}{0.08} \\
\hline Female & $53(45.3)$ & 37 (58.7) & \\
\hline \multicolumn{4}{|l|}{ Academic years } \\
\hline $1^{\text {st }}$ year & $15(12.8)$ & $29(46)$ & \multirow[t]{4}{*}{$0.001^{*}$} \\
\hline $2^{\text {nd }}$ year & $26(22.2)$ & $16(25.4)$ & \\
\hline $3^{\text {rd }}$ year & $35(29.9)$ & $11(17.5)$ & \\
\hline $4^{\text {th }}$ year & $41(35)$ & $7(11.1)$ & \\
\hline \multicolumn{4}{|l|}{ Marital status } \\
\hline Single & $110(94)$ & $59(93.7)$ & \multirow[t]{2}{*}{0.9} \\
\hline Married & $7(6)$ & $4(6.3)$ & \\
\hline \multicolumn{4}{|l|}{ Living } \\
\hline With family & $91(77.8)$ & $53(84.1)$ & \multirow[t]{3}{*}{0.32} \\
\hline With friends & $16(13.7)$ & $4(6.3)$ & \\
\hline In university campus & $10(8.5)$ & $6(9.5)$ & \\
\hline \multicolumn{4}{|l|}{$B M I^{a}$} \\
\hline Average BMI (18.5-24.9) & $48(41)$ & $51(81)$ & \multirow[t]{3}{*}{$0.001^{*}$} \\
\hline Overweight BMI (25-29.9) & $48(41)$ & $9(14.3)$ & \\
\hline Obese $\mathrm{BMI} \geq 30$ & $21(18)$ & $3(4.7)$ & \\
\hline \multicolumn{4}{|l|}{ Type of diet followed } \\
\hline High protein diet & $51(43.6)$ & $8(12.7)$ & \multirow[t]{3}{*}{$0.001^{*}$} \\
\hline Low fat diet & $38(32.5)$ & $9(14.3)$ & \\
\hline No specific diet followed & $28(23.9)$ & $46(73)$ & \\
\hline \multicolumn{4}{|c|}{ Food alone is enough to satisfy your nutritional needs } \\
\hline Yes & $29(24.8)$ & $39(61.9)$ & \multirow[t]{2}{*}{$0.001^{*}$} \\
\hline No & $88(75.2)$ & $24(38.1)$ & \\
\hline \multicolumn{4}{|l|}{ Self-rated health status } \\
\hline Excellent & $30(25.6)$ & $2(3.2)$ & \multirow[t]{4}{*}{$0.001^{*}$} \\
\hline Good & $50(42.7)$ & $16(25.4)$ & \\
\hline Fair & $33(28.2)$ & $34(54)$ & \\
\hline Below & $4(3.4)$ & $11(17.5)$ & \\
\hline \multicolumn{4}{|l|}{ Smoking } \\
\hline Current cigarette smoker & $4(3.4)$ & $18(28.6)$ & \multirow[t]{3}{*}{$0.001^{*}$} \\
\hline Ex-smoker & $6(5.1)$ & $1(1.6)$ & \\
\hline Never smoke & $107(91.5)$ & $44(69.8)$ & \\
\hline \multicolumn{4}{|l|}{ Practice regular exercise $^{c}$} \\
\hline Yes & $78(66.7)$ & $20(31.7)$ & \multirow[t]{2}{*}{$0.001^{*}$} \\
\hline No & 39 (33.3) & $43(68.3)$ & \\
\hline \multicolumn{4}{|c|}{ Reasons from regular exercise $(n=98)$} \\
\hline Increase muscle mass & $27(34.6)$ & $3(15)$ & \multirow[t]{4}{*}{$0.009^{*}$} \\
\hline Weight loss & $21(26.9)$ & $4(20)$ & \\
\hline Fitness and relief stress & $17(21.8)$ & $12(60)$ & \\
\hline Win the competition & $13(16.7)$ & $1(5)$ & \\
\hline Exercise duration/week /min ( & & & \\
\hline$<30 \min$ & $3(3.8)$ & $1(5)$ & $0.001^{*}$ \\
\hline $30-150 \mathrm{~min}$ & $14(17.9)$ & $12(60)$ & \\
\hline $150-300 \mathrm{~min}$ & $23(29.5)$ & $4(20)$ & \\
\hline More than $300 \mathrm{~min}$ & $38(48.7)$ & $3(15)$ & \\
\hline
\end{tabular}

${ }^{*} \mathrm{p}<0.05$. ${ }^{\mathrm{a} B o d y}$ mass index (BMl; measured weight in kilograms divided by measured height in meters squared) was categorized for repetitive adults according to the World Health Organization's cutfor underweight, healthy weight, overweight, and obese [18]. ${ }^{\text {'C }}$ Chi-square test or Fisher's exact test used and aim to improve or maintain the physical fitness [15], [19]. DS: Dietary supplements.

\section{Discussion}

The current study revealed that almost twothirds of participants $(65 \%)$ have taken DSs. Lieberman et al. reported similar results among college students in the USA (66\%), while higher rates of DS use were demonstrated in Saudi Arabia (76.6\%) [2], [15]. DS use started among freshmen (12.8\%) and increased with age to reach its maximum in the final academic year $(35 \%)$, as students during the university years become overly concerned about their body shape, stay on campus for a longer time, and become more influenced by their peers [20].

Many surveys have demonstrated that DS users adopt several positive health habits more than DS non-users [21], [22]. In this study, more than twothirds of the participants were doing regular exercises either to build muscle mass and win competitions (odds ratio $7.1, \mathrm{Cl} 1.9-25.03$ ) or to lose weight (odds ratio 3.7, $\mathrm{Cl}$ 1.01-13.6). Results from other studies aligned with these findings that $D S$ users commonly make their best efforts to be in good health and avoid obesity [21], [22]. Another Egyptian study illustrated that more than half of the participants of young Egyptian athletes (13-18 years old) use sports drinks (66.9\%) and creatine (54.3\%) [23]. Similarly, almost half of the DS users in Radwan et al. study engaged in regular exercise for three hours daily [24]. Furthermore, non-smoking, as a healthy habit, was more common among DS users, where the majority of DS users in this study were nonsmokers [25].

However, DS use may be associated with a possible negative consequence; students might consider DS as a substitute for a balanced healthy diet. Three-quarters of the users believed that food is not enough to meet their nutritional needs (odds ratio 4.9, $\mathrm{Cl}$ 2.6-9.5). Liberman et al. also highlighted this finding and recommended that national nutrition policies should encourage the consumption of healthy foods to maintain health instead of DS use [15].

Regarding the patterns of DS use, males and females were significantly different. The most types used were amino acids and proteins, multivitamins, and minerals and weight-loss herbals. Muscle building, promoting or maintaining good health, and managing weight were the leading motives for DS use. Half of the male students used mainly amino acids and proteins, followed by multivitamins and minerals $(17 \%)$, where they were mainly seeking to build muscles, gain more energy, and maintain good health. Yet, more than one-third of female students primarily consumed multivitamins and minerals for staying in good shape, and herbal supplements $(28.3 \%)$ for managing their weight. These findings were in alignment with the nationwide survey conducted in Japan among college students which declared that the main purpose for DS use was the health benefits among males and females, followed by muscle building for males and beauty supplements and weight management for females [16]. In five USA universities, college students (males and females) mainly used multivitamin or multi-mineral supplements, while protein or amino acid supplements were mainly used by male students [15]. In a study conducted in South East Asia, $43 \%$ of the Malaysian students were using vitamins and minerals [26]. In addition, male students at Ardabil University in Iran commonly used branched-chain amino acids and protein powder, while female students mainly used multivitamins and multiminerals [27].

The internet was the primary source of information for DS users. Male students depended on the internet as the main source of information, followed by coaches, then health-care providers, where they mostly bought DS on the internet. While females received the advice from healthcare providers, then the internet, and family members; besides, they bought DS mainly from pharmacies and after that on the internet. In most relevant studies, the sources of information werethesame, butthey differin orderand degree 
Table 3: Patterns of DSs use among the enrolled students $(n=117)$

\begin{tabular}{|c|c|c|c|c|}
\hline Variables & Total, $n(\%)(n=117)$ & Males, n (\%) 64 (54.7) & Females, n (\%) 53 (45.3) & $p$-value ${ }^{\star *}$ \\
\hline \multicolumn{5}{|l|}{ DSs used } \\
\hline Amino acids/protein & $36(30.8)$ & $35(54.7)$ & $1(1.9)$ & \multirow[t]{7}{*}{$0.0001^{*}$} \\
\hline Multivitamins and minerals & $30(25.6)$ & $11(17.2)$ & $19(35.8)$ & \\
\hline Herbals for weight loss & $19(16.2)$ & $4(6.3)$ & $15(28.3)$ & \\
\hline Individual minerals (iron, folic acid, zinc) & $12(10.3)$ & $1(1.6)$ & $11(20.8)$ & \\
\hline Individual vitamins $(B, C, D)$ & $10(8.5)$ & $4(6.3)$ & $6(11.3)$ & \\
\hline Creatinine & $6(5.1)$ & $6(9.4)$ & $0(0)$ & \\
\hline Omega 3 & $4(3.4)$ & $3(4.7)$ & $1(1.9)$ & \\
\hline \multicolumn{5}{|l|}{ Reasons for using DS } \\
\hline Muscle building & $32(27.4)$ & $32(50)$ & $0(0)$ & \multirow[t]{7}{*}{$0.001^{*}$} \\
\hline Promote/maintain good health & $27(23.1)$ & $9(14)$ & $18(34)$ & \\
\hline Weight loss & 19 (16.2) & $4(6.3)$ & $15(28.3)$ & \\
\hline Enhance the diet & $11(9.4)$ & $8(12.5)$ & $3(5.7)$ & \\
\hline Give more energy & $10(8.5)$ & $9(14.1)$ & $1(1.8)$ & \\
\hline Beauty (skin-hair) & $9(7.7)$ & $0(0)$ & $9(17)$ & \\
\hline Medical need/deficiency & $9(7.7)$ & $2(3.1)$ & $7(13.2)$ & \\
\hline \multicolumn{5}{|l|}{ Sources of information about DS } \\
\hline Internet & $28(23.9)$ & $15(23.4)$ & $13(24.5)$ & \multirow[t]{7}{*}{$0.001^{*}$} \\
\hline Health-care provider (physician-pharmacist) & $26(22.2)$ & $10(15.6)$ & $16(30.2)$ & \\
\hline Coach & $18(15.4)$ & $6(9.4)$ & $12(22.6)$ & \\
\hline Friends & 16 (13.7) & $9(14.1)$ & $7(13.2)$ & \\
\hline Family members & $13(11.1)$ & $13(20.3)$ & $0(0)$ & \\
\hline Television, newspaper , magazine & $9(7.7)$ & $4(6.3)$ & $5(9.4)$ & \\
\hline DSs store & $7(6)$ & $7(10.9)$ & $0(0)$ & \\
\hline \multicolumn{5}{|l|}{ Places of getting DS } \\
\hline Pharmacies & $40(34.2)$ & $10(15.6)$ & $30(56.6)$ & \multirow[t]{5}{*}{$0.003^{*}$} \\
\hline Electronic websites & $25(21.4)$ & $17(26.6)$ & $8(15.1)$ & \\
\hline Social media sites & $25(21.4)$ & $14(21.9)$ & $11(20.8)$ & \\
\hline Friends & $17(14.5)$ & $16(25)$ & $1(1.9)$ & \\
\hline DS store & $10(8.5)$ & $7(10.9)$ & $3(5.7)$ & \\
\hline \multicolumn{5}{|l|}{ Duration of use of DS } \\
\hline $1-4$ weeks & $27(23.1)$ & $6(9.4)$ & $21(39.6)$ & \multirow[t]{4}{*}{$0.001^{*}$} \\
\hline $1 \mathrm{~ms}-6 \mathrm{~ms}$ & $44(37.6)$ & $20(31.3)$ & $24(45.3)$ & \\
\hline $6 \mathrm{~ms}-1$ year & $36(30.8)$ & $29(45.2)$ & $7(13.2)$ & \\
\hline More than 1 year & $10(8.5)$ & $9(14.1)$ & $1(1.9)$ & \\
\hline
\end{tabular}

Table 4: Odds ratios for the association between selected demographic and lifestyle characteristics and aspects of DS use among the DS users

\begin{tabular}{|c|c|c|c|c|c|}
\hline \multirow[t]{2}{*}{ Variables } & \multicolumn{5}{|c|}{ Ever using any DSs } \\
\hline & $\mathrm{B}$ & SE & Odds ratio & $95 \%$ confidence interval & $\mathrm{p}$-value \\
\hline \multicolumn{6}{|l|}{ Sex } \\
\hline Male & 0.541 & 0.316 & 1.718 & $0.9-3.19$ & 0.087 \\
\hline Female & & & 1 & & \\
\hline $1^{\text {st }}$ year & - & - & 1 & & \\
\hline $2^{\text {nd }}$ year & 1.145 & 0.450 & 3.142 & $1.3-7.5$ & $0.011^{*}$ \\
\hline $3^{\text {rd }}$ year & 1.817 & 0.470 & 6.152 & $2.5-15.4$ & $0.001^{*}$ \\
\hline $4^{\text {th }}$ year & 2.427 & 0.518 & 11.324 & $4.1-31.3$ & $0.001^{*}$ \\
\hline \multicolumn{6}{|l|}{$\mathrm{BMI} \mathrm{I}^{\mathrm{a}}$} \\
\hline Overweight BMI (25-29.9) & 1.735 & 0.415 & 5.667 & $2.5-12.8$ & $0.0001^{*}$ \\
\hline Obese $\mathrm{BMI} \geq 30$ & 2.007 & 0.649 & 7.438 & $2.1-26.5$ & $0.002^{*}$ \\
\hline \multicolumn{6}{|l|}{ Type of diet followed } \\
\hline High protein diet & 2.349 & 0.450 & 10.473 & $4.3-25.2$ & $0.001^{*}$ \\
\hline Low fat diet & 1.937 & 0.441 & 6.937 & $2.9-16.5$ & $0.001^{*}$ \\
\hline No specific diet followed & - & - & 1 & & \\
\hline \multicolumn{6}{|l|}{ Food alone is enough to satisfy your nutritional needs } \\
\hline Yes & - & - & 1 & & \\
\hline No & 1.596 & 0.336 & 4.931 & $2.6-9.5$ & $0.0001^{*}$ \\
\hline \multicolumn{6}{|l|}{ Self-rated health status } \\
\hline \multicolumn{6}{|l|}{ Smoking } \\
\hline Current cigarette smoker & - & & 1 & $3.6-35.2$ & $0.0001^{*}$ \\
\hline Non-smoker(never/former) & 2.425 & 0.580 & 11.3 & & \\
\hline \multicolumn{6}{|l|}{ Practice regular exercise $\mathrm{b}^{\mathrm{b}}$} \\
\hline Yes & 1.459 & 0.334 & 4.30 & $2.2-8.3$ & $0.0001^{*}$ \\
\hline No & - & - & 1 & & \\
\hline Reasons from regular exercise $(n=98)$ increase muscle mass/win competition & 1.954 & 0.646 & 7.1 & $1.9-25.03$ & $0.002^{*}$ \\
\hline Weight loss & 1.310 & 0.663 & 3.7 & $1.01-13.6$ & $0.048^{*}$ \\
\hline Fitness and relief stress & - & & 1 & & \\
\hline \multicolumn{6}{|l|}{ Exercise duration $/$ week $/ \mathrm{min}(n=98)$} \\
\hline$<30 \mathrm{~min}$ & - & - & 1 & & \\
\hline $30-150 \mathrm{~min}$ & -0.944 & 1.220 & 0.389 & $0.036-4.25$ & 0.439 \\
\hline $150-300 \mathrm{~min}$ & 0.651 & 1.275 & 1.917 & $0.16-23.3$ & 0.610 \\
\hline More than $300 \mathrm{~min}$ & 1.440 & 1.301 & 4.222 & $0.33-54.1$ & 0.268 \\
\hline
\end{tabular}

of importance. In Japan, for example, the internet and the stores are the most common sources of information, and college students commonly get the DS from pharmacies or drug stores, followed by the internet [16]. In the USA, male college students preferred to acquire information from the internet, followed by friends and trainers, whereas female students received information from family members and health-care providers, respectively [15]. On the contrary, in the UAE, health-care providers were the most common and trustworthy source of information among students; 
therefore, students commonly got the DS from pharmacies more than the health club stores and the supermarkets [14].

In addition, this study was concerned to uncover the refraining reasons for DS non-users. One-third of the participants have never taken DS. Female non-users declared that the main reason was the lack of enough information about DS, followed by fear of complications, while the expenses were the main obstacle for male students and the nonexistence of need comes next. Similar reasons, in different order though, were also given in studies by Axon et al. and Fattahzadeh-Ardalani et al., in which the participants thought that they did not need DS, or they did not believe in their effectiveness, followed by the problem of expenses [27], [28].

\section{Conclusion}

DSs use was prevalent among more than twothirds of the participants from Helwan College students who consumed these products as a part of their healthy lifestyle. This obvious DS use may be concerning as a habit established during university years that could persist through adult life. Building muscle mass, weight management, and maintaining good health were the main motives for DS use. The most commonly used DS were amino acids and proteins, herbals for weight management, and multivitamins and minerals. This study explored the patterns of DS use, a contribution that can help foster a heightened awareness and education intervention about the reality and myths of DS, consequently prevent possible future adverse effects of DS use among college students. Furthermore, the study could be a base for a nationwide survey assessing the consumption of DS among all age groups, sexes, and social classes in Egypt.

\section{Study limitations}

This was an exploratory cross-sectional study used a consecutive non-probability sample of students from one college, who accepted to share in the study. Hence, we cannot generalize the results for all the students at Helwan University. However, due to the paucity of studies addressing this point, this study aimed to explore the patterns of Ds use among college students, to be a base for further studies on a wide scale; the objectives were achieved.

\section{Availability of Data and Materials}

Available on reasonable request.

\section{Acknowledgments}

The authors acknowledge the college students who agreed to participate in our study. The authors also thank and appreciate the administration of Helwan University and the College of Law for approving the data collection.

\section{Contributions}

$\mathrm{NH}$ contributed to the study design, analysis, and interpretation of the student's data regarding the pattern of DSs use and wrote the discussion and conclusion. $\mathrm{AH}$ was a major contributor to revise the introduction and discussion. MR wrote the methods section, revised the discussion and conclusion, and contributed to writing the manuscript. HS supervised the study and revised the manuscript. All authors read and approved the final manuscript.

\section{References}

1. Food Drug Administration. Dietary Supplement Health and Education Act of 1994 Public Law 103-417103 $3^{\text {rd }}$ Congress. United States: Food Drug Administration; 1994.

2. Alfawaz $H$, Khan N, Alfaifi A, Shahrani FM, Al Tameem HM, Al Otaibi SF, et al. Prevalence of dietary supplement use and associated factors among female college students in Saudi Arabia. BMC Womens Health. 2017;17(1):116. https://doi. org/10.1186/s12905-017-0475-y

PMid:29166929

3. Marcus DM, Grollman AP. The consequences of ineffective regulation of dietary supplements. Arch Intern Med. 2012;172(13):1035-6. https://doi.org/10.1001/ archinternmed.2012.2687 PMid:22777632

4. Gahche J. Dietary supplement use among US adults has increased since NHANES III (1988-1994). NCHS Data Brief. 2011;61:1-8

PMid:21592424

5. Burns C, Cook K, Mavoa H. Role of expendable income and price in food choice by low income families. Appetite. 2013;71:209-17. https://doi.org/10.1016/j.appet.2013.08.018 PMid:24008182

6. Euromonitor International. Vitamins and Dietary Supplements in Middle East and Africa; 2018. Available from: https://www. euromonitor.com/vitamins-and-dietary-supplements-in-middleeast-and-africa/report. [Last accessed on 2020 Jan 20].

7. Euromonitor International. Country Report: Vitamins in Egypt 2017. Available from: http://www.euromonitor.com/vitamins-inegypt/report. [Last accessed on 2019 Dec 08].

8. Grand View Research. Dietary Supplements Market Size Worth \$278.02 Billion By 2024: GRAND VIEW RESEARCH; 2018. Available from: https://www.grandviewresearch.com/ 
press-release/global-dietary-supplements-market.

[Last accessed on 2020 Jan 01].

9. National Institutes of Health. Office of Dietary Supplements: Multivitamin/Mineral Supplements Fact Sheet for Healthcare Professionals; 2015. Available from: https://www.ods.od.nih. gov/factsheets/MVMS-HealthProfessional. [Last accessed on 2020 Jun 15].

10. Knapik JJ, Steelman RA, Hoedebecke SS, Austin KG, Farina EK, Lieberman HR. Prevalence of dietary supplement use by athletes: Systematic review and meta-analysis. Sports Med. 2016;46(1):103-23. https://doi.org/10.1007/s40279-015-0387-7 PMid:26442916

11. Bianco A, Mammina C, Thomas E, Ciulla F, Pupella U, Gagliardo F, et al. Protein supplements consumption: A comparative study between the city centre and the suburbs of Palermo, Italy. BMC Sports Sci Med Rehabil. 2014;6(1):29. https://doi.org/10.1186/2052-1847-6-29 PMid:25089201

12. Mamtani R, Cheema S, MacRae B, Alrouh H, Lopez T, ElHajj M, et al. Herbal and nutritional supplement use among college students in Qatar. East Mediterr Health J. 2015;21(1):39-44. https://doi.org/10.26719/2015.21.1.39 PMid:25907191

13. Barnes K, Ball L, Desbrow B, Alsharairi N, Ahmed F. Consumption and reasons for use of dietary supplements in an Australian university population. Nutrition. 2016;32(5):524-30. https://doi.org/10.1016/j.nut.2015.10.022 PMid:26819063

14. Alhomoud FK, Basil M, Bondarev A. Knowledge, attitudes and practices (KAP) relating to dietary supplements among health sciences and non-health sciences students in one of the universities of United Arab Emirates (UAE). J Clin Diagn Res. 2016;10(9):JC05. https://doi.org/10.7860/jcdr/2016/19300.8439 PMid:27790468

15. Lieberman HR, Marriott BP, Williams C, Judelson DA, Glickman EL, Geiselman PJ, et al. Patterns of dietary supplement use among college students. Clin Nutr. 2015;34(5):976-85. https://doi.org/10.1016/j.clnu.2014.10.010 PMid:25466950

16. Kobayashi E, Sato $\mathrm{Y}$, Umegaki K, Chiba T. The prevalence of dietary supplement use among college students: A nationwide survey in Japan. Nutrients. 2017;9(11):1250. https://doi. org/10.3390/nu9111250 PMid:29140269

17. Sirico F, Miressi S, Castaldo C, Spera R, Montagnani S, Di Meglio F, et al. Habits and beliefs related to food supplements: Results of a survey among Italian students of different education fields and levels. PLoS One. 2018;13(1):e0191424. https://doi. org/10.1371/journal.pone.0191424 PMid:29351568

18. World Health Organization. Obesity: Preventing and Managing the Global Epidemic. Geneva: World Health Organization; 2000.

19. World Health Organization. Physical Activity Key Facts; 2018. Available from: https://www.who.int/news-room/fact-sheets/ detail/physical-activity. [Last accessed on 2020 May 11].

20. Naqvi AA, Ahmad R, Elewi AA, AIAwa AH, Alasiri MJ. Dietary supplement use among undergraduate male students in health and non-health cluster colleges of a public-sector university in Dammam, Saudi Arabia. BMC Complement Altern Med. 2018;18(1):269. https://doi.org/10.1186/s12906-018-2332-4 PMid:30285802

21. Foote JA, Murphy SP, Wilkens LR, Hankin JH, Henderson BE, Kolonel LN. Factors associated with dietary supplement use among healthy adults of five ethnicities: The multiethnic cohort study. Am J Epidemiol. 2003;157(10):888-97. https://doi. org/10.1093/aje/kwg072

PMid:12746241

22. Bailey RL, Gahche JJ, Miller PE, Thomas PR, Dwyer JT. Why US adults use dietary supplements. JAMA Intern Med. 2013;173(5):355-61. https://doi.org/10.1001/ jamainternmed.2013.2299 PMid:23381623

23. Tawfik S, El Koofy N, Moawad EM. Patterns of nutrition and dietary supplements use in young Egyptian athletes: A communitybased cross-sectional survey. PLoS One. 2016;11(8):e0161252. https://doi.org/10.1371/journal.pone.0161252 PMid:27529492

24. Radwan H, Hasan HA, Ghanem L, Alnajjar G, Shabir A Alshamsi $A$, et al. Prevalence of dietary supplement use and associated factors among college students in the United Arab Emirates. J Community Health. 2019;44(6):1135-40. https://doi. org/10.1007/s10900-019-00700-2 PMid:31273622

25. Alowais MA, Selim MA. Knowledge, attitude, and practices regarding dietary supplements in Saudi Arabia. J Family Med Prim Care. 2019;8(2):365. https://doi.org/10.4103/jfmpc. jfmpc_430_18 PMid:30984640

26. Al-Naggar RA, Chen R. Prevalence of vitamin-mineral supplements use and associated factors among young Malaysians. Asian Pac J Cancer Prev. 2011;12(4):1023-9. PMid:21790245

27. Fattahzadeh-Ardalani G, Farzaneh E, Fathi A, Molaei B, Valizadeh M. Determining the prevalence of dietary supplement consumption among Ardabil university students and related factors, 2014. Int J Community Med Public Health. 2016;3(1):2249. https://doi.org/10.18203/2394-6040.ijcmph20151567

28. Axon DR, Vanova J, Edel C, Slack M. Dietary supplement use knowledge, and perceptions among student pharmacists. Am J Pharm Educ. 2017;81(5):92. https://doi.org/10.5688/ajpe81592 PMid:28720920 